\title{
Introduction to Special Issue: Exploring Ritual Fields Today
}

\author{
Martin Hoondert *(D) and Paul Post* \\ Tilburg School of Humanities and Digital Sciences, Tilburg University, P.O. Box 90153, \\ 5000 LE Tilburg, The Netherlands \\ * Correspondence: M.J.M.Hoondert@tilburguniversity.edu (M.H.); P.G.J.Post@tilburguniversity.edu (P.P.)
}

Citation: Hoondert, Martin, and Paul Post. 2021. Introduction to Special Issue: Exploring Ritual Fields Today. Religions 12: 210. https:// doi.org/10.3390/rel12030210

Received: 18 February 2021

Accepted: 12 March 2021

Published: 19 March 2021

Publisher's Note: MDPI stays neutral with regard to jurisdictional claims in published maps and institutional affiliations.
Due to the COVID-19 crisis and the related restrictive measures, many of our (daily) rituals have changed. At the same time, new rituals have emerged. The usual habit of greeting each other with a handshake or a kiss has been replaced by a gesture of bowing, a nod of the head, or a hand on the heart. Weddings have been canceled or postponed to after the crisis, and funerals take place with a limited number of participants. Rituals, although appearing to be traditional and fixed, are very much contextual and subject to change. Indeed, rituals are not performed in a vacuum, nor are they independent of time and place. Rituals are deeply influenced by the cultural, social, economic, and political contexts in which they appear. Trends in culture also lead to ritual changes. Thus, the study of rituals is a dynamic field, and it is exactly this idea that is reflected in this Special Issue of Religions that is focused on "Exploring Ritual Fields Today."

Through the contributions to this Special Issue, we want to project an image of what a ritual is today and of the contemporary ritual studies. In this introduction, we present the main theme of this Special Issue, review the separate contributions, and provide an overview of ritual studies as an academic field. We chose to approach this issue from a Dutch perspective, for that is the context in which we, as the editors and nearly all the authors, are based.

\section{Approaching Rituals Today \\ 1.1. Ritual}

We start with a working definition of a ritual, derived from the work of many other ritual studies scholars, including, among others, Ronald Grimes. We define the concept "ritual" in a broad and open way as follows:

... [A ritual is] a more or less repeatable sequence of action units which take on a symbolic dimension through formalization, stylization, and their situation in place and time. On the one hand, individuals and groups express their ideas and ideals, their mentalities and identities through these rituals, on the other hand, the ritual actions shape, foster, and transform these ideas, mentalities, and identities. (Post 2015)

It is by no means our intention to suggest that we can clearly demarcate the boundaries of the concept with this working definition. Instead, the definition serves as an indication of what we can call a "core ritual" or a "full ritual," but it does not necessarily exclude other practices from having a ritual dimension. In ritual studies, we distinguish between rituals, ritualizing, and ritual-like practices (Post and Hoondert 2019, p. 10). Here, we follow Catherine Bell (1997), who presents alongside full rituals, ritual practices, and ritual behaviors with a ritual character (pp. 138-69). As an example, we can refer to current practices after a disaster or terrorist attack. In such a context, we see all kinds of practices that aim at expressing compassion, solidarity, anger, and protest. We have seen how cities all over the world expressed their solidarity by marking characteristic buildings with lasers and LED lights in the colors of the French flag after the Charlie Hebdo attacks in November 2015. Another example is the popularity of bee tattoos after the Manchester Arena attack during a performance by Ariana Grande in 2017 (the bee is the symbol of Manchester). A 
third example can be drawn from the current COVID-19 pandemic. In the first few months of March-May 2020, we witnessed people singing songs of hope from their balconies and applauding the staff of overcrowded hospitals (e.g., in The Netherlands, the UK, and Spain). These examples involve practices with a ritual character, but are they "full rituals"?

Not everyone in ritual studies is happy with this search for a definition, even if it is only for a provisional and open working description. Many have taken a different route in looking for a series of "qualities of ritual" as they search for a so-called polythetic definition (Grimes 1990; McClymond 2016; Rappaport and Rappaport 1999; Snoek 2006). A polythetic definition works with a set of characteristics that may be applied to a particular phenomenon but do not necessarily have to, as opposed to a monothetic definition that uses exclusive criteria that all have to apply in a particular case. Those qualities or characteristics can take various forms. For instance, they can be "family characteristics of ritual," as proposed by Grimes (2014, p. 194). Grimes mentions various ways in which people ritualize their practices, including by traditionalizing, elevating, repeating, singularizing, prescribing, stylizing, and situating them in specific places and times. Others, like Gerard Lukken, list characteristics and qualities as functions or dimensions that together provide an image of what a ritual is and is capable of. Frequently mentioned functions of a ritual are channeling feelings and emotions, paying attention, expressing ideas and ideals, coping with contingency, and socializing (Lukken 2005; Post 2003).

In our opinion, both approaches to defining the concept "ritual" complement each other. On the one hand, we can use an open working definition, while on the other, we can employ the aforementioned sets of characteristics, strategies, and functions in the description, analysis, and evaluation of ritual practices.

\subsection{Ritual Fields and Repertoires}

In current ritual studies, the insight has been shared that rituals are definitely not traditional in the sense of being invariable and not subject to change. On the contrary, rituals are mobile, dynamic, and changing. Rituals can be found in several spaces and cultural domains. We distinguish six "ritual fields" (i.e., cultural domains in which rituals can be traced). We present these ritual fields briefly here, but not without first stating that these fields are closely related to each other and partly overlap (see also Post 2013):

1. The cycle of the year and the seasons can be ritualized. Bell refers to these as calendrical rituals, which are in many cases determined by the moon or sun calendar.

2. The cycle of life is another ritual field in which we encounter rituals related to birth and death. Some are calendrical and return every year, while others are occasionally practiced. In this field, as well as in the cycle of the year and seasons, time is a key word.

3. Religion is, even in secularized countries, an important space within which rituals take place.

4. Memory culture is oriented toward dealing with the past in a ritual way. There is an extensive commemorative culture regarding the First and Second World Wars. Commemorative practices range from grassroots rituals (Margry and Sánchez-Carretero 2011) to postponed rituals (Faro 2015). After an accident or an attack in the public domain, we see all kinds of grassroots rituals as flowers, lights, and notes are left on the spot. Roadside memorials are also widespread. There is also ritual marking that literally finds its place only after decades, as in the case of the Holocaust Mahnmal in Berlin that was not opened until 2005.

5. Artistic practices are very often ritualized. In the museum and the theater, ritual rules apply, and for many people, artistic practices function as meaning-making practices in the same way as religion does.

6. Leisure culture, such as sports and tourism, is full of rituals. One might think of the soccer player who kisses the sign of the cross before the match starts or the longdistance runner on his way to an ancient pilgrimage site. In this ritual field, we also see many debates regarding heritage. 
Within these ritual fields, we can distinguish several so-called ritual repertoires. Although there is a direct relation between the fields and the repertoires, the focus of a ritual repertoire is not so much on a cultural domain as it is on being a unit of ritual practices that share a certain coherence in terms of form and design, or manifestation and participation. A good example of a ritual repertoire is food rituals. We can trace them within the field of religion (e.g., Eucharist, the Last Supper, and offerings of food in Hindu rituals), but also in the field of life cycles: No birthday celebration can be held without cake and other delicacies. Another example is silence or meditation. This repertoire is part of the fields of religion, artistic practices (e.g., the rule not to applaud after each section of a concerto), and memory culture (e.g., the one or two minutes of silence as an expression of respect to victims of war and violence).

As already indicated, these ritual fields are important for understanding the dynamics regarding rituals in contemporary culture. In the so-called network culture, there is a constant "flow" between and through these fields. Two examples make this clear. First, an abbey or monastery in (post)modern Western Europe is still a religious center of prayer and contemplation. At the same time, it is a place for relaxation, heritage, or nature experience, health and well-being, and good and honest food. Second, the popularity of the Camino $^{1}$, the old pilgrimage to Santiago de Compostela, is directly linked to the fact that this ritual is embedded in almost all fields. For some, the pilgrimage is a religious endeavor, whereas for others, it is a sporting adventure or a cultural-historical route along interesting heritage centers.

\section{Ritual Studies in The Netherlands}

As said at the start, we as the editors and most of the authors in this issue are based in the Netherlands, in which ritual studies is a small but dynamic field of research. The situation of ritual studies in the Netherlands concerns a relatively small and rather wellorganized area of all kinds of partnerships and platforms of cooperation. At the same time, research in ritual studies is diffuse because it is fragmented across more than ten universities and as many faculties, departments, and research institutes.

We start with the multidisciplinary platforms and networks that bundle the research. First, we must consider the Institute of Ritual and Liturgical Studies (IRILIS) ${ }^{2}$, currently coordinated by the Protestant Theological University (PThU) in Amsterdam. The primary participants of this network organization include the PThU, the Humanities and Theology Schools of Tilburg University, the Center for Religion and Heritage of the Faculty of Theology and Religious Studies of Groningen University, the Center for Thanatology and the Benedictine Center for Liturgical Studies, both at Radboud University in Nijmegen, and the University of Humanistic Studies in Utrecht. The IRILIS mainly manifests and profiles itself through a series of publications, of which Netherlands Studies in Ritual and Liturgy and Liturgia Condenda are the most important. The IRILIS is currently working on a large international handbook project on disaster rituals.

Each participant of the IRILIS brings their own expertise and profile in ritual studies. The PThU ${ }^{3}$ researches liturgical rituals mainly in the context of practical theology (with researchers including Marcel Barnard Mirella Klomp). Recent themes have included meals and food, the Passion, and youth culture. The Tilburg School of Humanities and Digital Culture $^{4}$ focuses on current funeral rituals, rituals in care centers like hospices, online rituals, rituals of victimhood, space, and place, rituals and religious diversity, absent rituals, and, in particular, ritual music, such as music in cremations and the popularity of passions and requiems (researchers include Martin Hoondert, Albertina Nugteren, Janieke BruinMollenhorst, Paul Post, and Herman Beck). The Tilburg School of Humanities and Digital

\footnotetext{
In 2005, there were 93,924 pilgrims who officially registered their pilgrimage in the pilgrims' office in Santiago de Compostela; in 2019, this number reached 347,578 (Oficina Peregrino).

2 https://www.pthu.nl/irilis/ (accessed on 8 October 2020).

https://www.pthu.nl/ (accessed on 8 October 2020).

https:/ /www.pthu.nl/irilis/ (accessed on 8 October 2020).
} 
Culture has initiated two platforms for cooperation between academics and experts or professionals outside of academia. The Funerary Academy ${ }^{5}$ is a platform of researchers and professionals in the funeral industry, and the Camino Academy ${ }^{6}$ has initiated research in the field of pilgrimage, with a specific focus on the route to Santiago de Compostela.

Within the Tilburg School of Catholic Theology ${ }^{7}$, the emphasis is more on liturgy, theology, and ritual through a sociology of religion perspective (with researchers including Sam Goyvaerts and William Arfman). The Groningen Center for Religion and Heritage ${ }^{8}$ focuses on the interplay of religion and heritage from a theoretical and practical perspective (with researchers including Todd Weir and Andrew Irving). Their projects focus on material culture, such as church buildings.

The Nijmegen Center for Thanatology ${ }^{9}$ (led by Eric Venbrux) conducts research into the socio-cultural and religious aspects of death, dying, and bereavement. Particular attention is paid to the processes of change in the funeral culture through comparative research.

At the University of Humanistic Studies ${ }^{10}$ (Utrecht), Joanna Wojtkowiak conducts research into the psychological, spiritual, and existential aspects of rituals, and life cycle rituals in particular. The University of Humanistic Studies offers an education program for celebrants who are trained in ritual practices in secular and/or non-institutional religious settings.

The (European) ethnology research group of the Meertens Institute ${ }^{11}$, which is part of the Humanities cluster of the Royal Netherlands Academy of Arts and Sciences in Amsterdam (with researchers including Peter Jan Margry, Irene Stengs, and Ernst van den Hemel), has initiated projects that focus on the culture of everyday life, identity and heritage, new forms of religiosity, the framing of rituals, healing practices, and the culture of remembrance in the public domain. A great deal of research is currently taking place within the context of the HERILIGION program, which refers to the heritagization of religion and sacralization of heritage. ${ }^{12}$ At Utrecht University, there is another influential research group led by the anthropologist of religion Birgit Meyer. Meyer conducts research on popular culture and heritage, material and visual culture, religious and ritual sounds, food practices, religious buildings, and space. After the conclusion of the international research program Iconic Religion ${ }^{13}$, the project Religious Matters in an Entangled World was initiated. ${ }^{14}$

In Rotterdam (Erasmus University) at the School of History, Culture and Communication, the research group led by Stijn Reijnders ${ }^{15}$ has been working on projects at the intersection of media, culture, and communication for years. The focus here has been on "locating imagination" through research into tourism and place-oriented practices. These projects concern cultural heritage, food culture, the significance of battlefield tours for the military, and the attraction of film locations.

In addition to universities and academic centers, there are universities of applied sciences where interesting research on rituals is conducted from a practical perspective. We find it important to mention the Breda University of Applied Sciences, where Rami Isaac conducts research into tourism and memorial culture, dark tourism, and risky traveling. There is also the Reinwardt Academy in Amsterdam that trains heritage and museum professionals. This academy is currently conducting a research program on "emotion networks" and dealing with the past led by Hesther Dibbits. Hogeschool Windesheim in

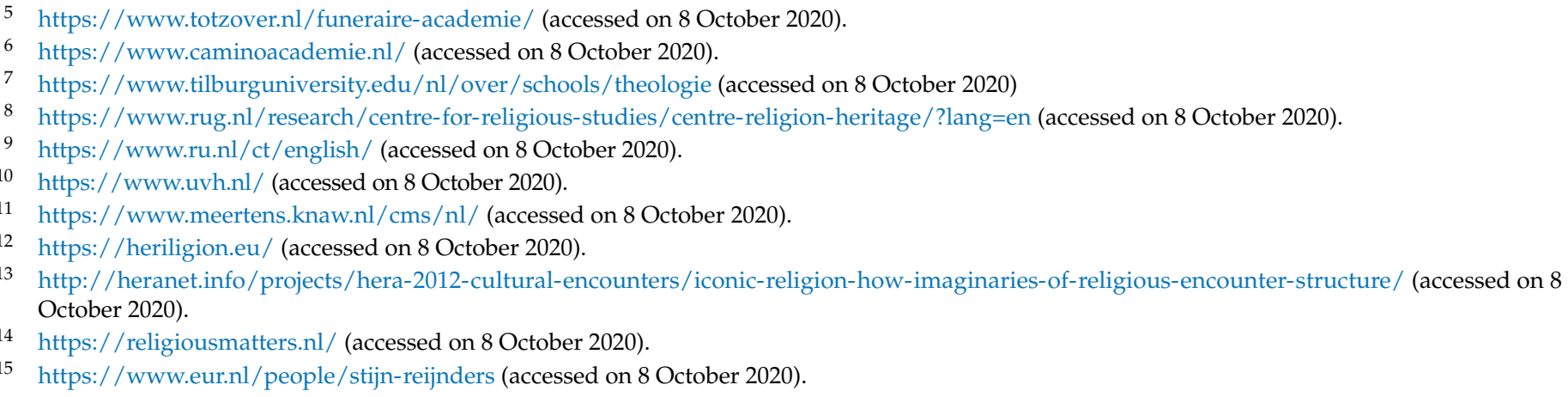


Zwolle (with the researcher André Mulder ${ }^{16}$ ) also conducts research into ritual counselors and rituals in healthcare.

Death Research in the Netherlands (Dood Onderzoek Nederland, DONE) is a growing national network of researchers in death studies. ${ }^{17}$ Senior and junior researchers from almost all Dutch universities have regular meetings, organize seminars, and cooperate in research projects regarding death, dying, bereavement, and grief.

If we now take stock and look at what ritual studies in the Netherlands focus on, certain emphases emerge. In general, almost all research in the domain of ritual studies in the Netherlands is about dynamics and change, the role of emerging rituals, and the ways in which ritual repertoires can be rooted in an ever-changing and fragmented culture. Cultural, religious, and ritual diversity and the search for identity are common keywords in this research. We also note that research into e-rituals is relatively scarce (van der Beek et al. 2019). We may expect that the COVID-19 pandemic and the sudden boom of all kinds of rituals online may be an incentive to study this area in the near future.

\section{Outline of This Special Issue}

The eight articles of this Special Issue represent both the ritual fields and repertoires, as described in the first section, and ritual studies as an academic, multidisciplinary platform, as described in the second section.

In her work, Joanna Wojtkowiak represents the field of life cycle rituals in her exploration of the ritualization of pregnancy and childbirth. While traditional birth rituals have been decreasing in popularity, new rituals have emerged, such as mother blessings and humanist naming ceremonies. Her article is a good example of the dynamics of rituals in showing that in a new, cultural environment, new rituals are invented, re-invented, and transferred from one context to another.

The articles by Albertina Nugteren, Sam Goyvaerts et al., Christoph Jedan et al., and Kim van der Weegen et al. fit in the same category of life cycle rituals. Albertina Nugteren critically reviews Western responses to Hindu widow-burning in India. Although this rare ritual practice has been banned for almost 200 years, it still evokes Western interest and criticism. Nugteren pleas for a contextual approach of rituals and, in accordance with it, a place- and time-sensitive type of ritual criticism. What strikes us as especially insightful in her well-informed article is the fact that Western scholars, through the culturally determined terminology they use, do not really understand the full meaning and impact of a ritual. Regarding "co-cremation," a concept that reflects a Western view of an Indian Hindu ritual practice, Nugteren writes the following:

It was not the death of her husband that had made her a widow, but her choice between two rituals would make her either a widow (containing everything the life and status of a widow implied) or a sati. For her, this was not simply a choice between life and death, but a choice between two religious paths, either of which would define her as a good woman, and would define both rituals as demonstrating her womanly power for the salvation of her husband. Whatever choice she would make, this soteriological power changed her, momentarily, from a victim to a victor.

Sam Goyvaerts and Nikolaas Vande Keere investigate the transformation of a Roman Catholic Church into a contemporary space for spirituality and commemoration. The concept of place is key in their study, as they link recent changes in funeral rituals in Flanders, Belgium, with the adaptive reuse project of a small church, which has been re-designed as a columbarium church, with the surrounding landscape being used for a spiritual and ritual "journey." This symbolizes the transition from life to death and from a life with the physical presence of the deceased to a life without it. Rather than considering the reuse of the church a spiritual loss, Goyvaerts and Vande Keere show how it can offer

https://www.windesheim.nl/onderzoek/deskundigen/mulder (accessed on 8 October 2020).

7 https://www.totzover.nl/done/ (accessed on 8 October 2020). 
the opportunity to reinforce and open up the traditional symbolic and ritual meaning of the Christian liturgy to the larger community. The article by Goyvaerts and Vande Keere demonstrates that ritual fields overlap. Accordingly, the article fits the fields of religion (through the church building and Christian liturgy) and life cycle rituals (through cremation and death rituals) with a close link to memory culture (i.e., the columbarium as materialization of memory).

In the article by Christoph Jedan, Sonja Kmec, Thomas Kolnberger, Eric Venbrux, and Mariske Westendorp, place is the key concept as they analyze a cemetery in the south of the Netherlands as a ritual space. From a ritual-spatial perspective, they show how cemeteries not only form an ensemble of ritual spaces that are reliant on preexisting communities, but they also evoke, produce, and maintain communities. Using several spatial theories, the authors consider the cemetery as a pluralistic ritual space that is continuously (re)constituted and (re)negotiated by administrators, users, and their allies.

A fourth and last article in the field of life cycle rituals is presented by Kim van der Weegen, Martin Hoondert, Agnes van der Heide, and Madeleine Timmermann. In this case, the authors investigate ritualized care practices in a hospice using an open and broad approach to rituals and ritual-like practices. In doing so, they distinguish between several types of rituals: (1) Care practices in the morning, (2) meals, (3) care practices in the evening, (4) care practices in the dying phase, and (5) a farewell ritual after a patient has died. Some of these practices are part of the daily routines, while others fit the category of life cycle rituals. Due to the environment of the hospice and the situation of the patients in the phase of dying, all actions take on a symbolic significance in their relation to the moral value of the "good death."

Another article regarding the reuse of church buildings is presented by Kim de Wildt, in which she focuses on the circumstances that precede the reuse of (Roman Catholic) church buildings: The deconsecration or profanation of the building. As such, the article fits the ritual field of religion. De Wildt explores the tension between the "legitimate" way (in the sense of canon law) to deconsecrate a church building and the growing pastoral need for deconsecration rites. With respect to deconsecration rites, a shift has taken place in the perception of reasons as to why such a rite should be conducted. In contrast to historical requirements that were mainly focused on such acts for the purpose of defining the "legitimate" way of relegating the church to profane use, the well-being of the affected parishioners today seems to be the main reason for the performance of such rites. Based on her critical review of current ritual practices, De Wildt proposes a distinction between the act of church deconsecration and the last farewell celebration.

The two remaining articles belong to the field of religion. Thomas Quartier, a Benedictine monk himself, answers the question of what ritual practices laypersons affiliated with a particular Benedictine monastery (so-called oblates) perform. The key concept in this article is "ritual transfer," through which monastic rituals, which are partly calendrical, are transferred to a new context (i.e., the lives of laypersons living outside the monastery). Quartier's qualitative research sheds some insight into the difficulties of transferring Christian, monastic rituals to a secular context. In the other article, John Eade reflects on two totally different types of pilgrimage: the one to the Catholic shrine of Lourdes, France, and the one to the pre-Christian shrine of Avebury, England. The focus of his research is on leadership, power, and authority in ritual invention and performance. In particular, the pilgrimage to Avebury shows the overlap of the ritual fields, as many walkers are not involved in institutional religion and express a wide variety of reasons for traveling along both ancient and emerging routes of pilgrimage. The popularity of walking seems to be an important impetus for the increasing popularity of such pilgrimages. An overlap of the fields of religion (sacred sites), leisure culture (walking), and memory culture (heritage) seems to position the pilgrimage as a successful and popular ritual despite secularization and a decrease in church attendance. 
The articles in this Special Issue show the dynamics of rituals in current societies. These dynamics are not only linked to the changing character of the rituals themselves, but also to the overlapping of the ritual fields and the transfer between them.

Funding: This research received no external funding.

Conflicts of Interest: The authors declare no conflict of interest.

\section{References}

Bell, Catherine M. 1997. Ritual: Perspectives and Dimensions. Oxford: Oxford University Press.

Faro, Laurie. 2015. Postponed Monuments in the Netherlands: Manifestation, Context, and Meaning. Tilburg: Tilburg University.

Grimes, Ronald L. 1990. Ritual Criticism: Case Studies in Its Practice, Essays on Its Theory. Columbia: University of South Carolina Press. Grimes, Ronald L. 2014. The Craft of Ritual Studies. Oxford: Oxford University Press.

Lukken, Gerard. 2005. Rituals in Abundance: Critical Reflections on the Place, form, and Identity of Christian Ritual in our Culture. Leuven: Peeters. Margry, Peter Jan, and Cristina Sánchez-Carretero. 2011. Grassroots Memorials: The Politics of Memorializing Traumatic Death. New York: Berghahn Books.

McClymond, K. 2016. Ritual gone wrong: What we learn from ritual disruption. Oxford: Oxford University Press.

Post, Paul, and Martin Hoondert. 2019. Absent Ritual: Exploring the Ambivalence and Dynamics of Ritual. Durham: Carolina Academic Press.

Post, Paul. 2013. From identity to accent. The Ritual Studies perspective of Fields of the Sacred. Pastoraltheologische Informationen 33: $149-58$.

Post, Paul. 2015. Ritual studies. In Oxford Research Encyclopedia of Religion. Oxford: Oxford University Press. [CrossRef]

Post, Paulus Gijsbertus Johannes. 2003. Disaster ritual: Explorations of an Emerging Ritual Repertoire. Leuven: Peeters.

Rappaport, Roy A., and Roy Abraham Rappaport Rappaport. 1999. Ritual and Religion in the Making of Humanity. Cambridge: Cambridge University Press.

Snoek, Jan A. M. 2006. Defining rituals. In Theorizing Rituals I: Issues, Topics, Approaches, Concepts. Edited by Jens Kreinath, Joannes Augustinus Maria Snoek and Michael Stausberg. Leiden: Brill, pp. 3-14.

van der Beek, Suzanne, Martin Hoondert, Janieke Bruin-Mollenhorst, Nicolas Matthee, Mike de Kreek, Karin Wenz, Sarah J. Griffiths, and Wahyu Ilaihi. 2019. Ritual in a Digital Society. Tilburg/Groningen: Institute for Ritual and Liturgical Studies/Centre of Religion and Heritage Studies. 